\title{
What is Behind the China Rule in 2007: Motivations for the Bush Administration's Export Control Policy Against China
}

\author{
Sanghyun Han
}

\begin{abstract}
Although export control policy for dual-use items has been getting attention recently, particularly due to the Trump administration's frequent usage of the term, it is worth noting that the history of post-Cold War export control policy dates back to 2007-i.e., during the Bush administration. China Rule, as an export control policy, rather than an ordinary export policy, provides the foundation for controlling export toward China. This study examines why the Bush administration implemented such a policy specifically in 2007, and then moves on to specify China Rule as the dependent variable. With an emphasis on both perceptual and cognitive aspects of human decision-makers, the theoretical framework not only draws from the area of foreign policy analysis, but builds on the concept of securitization to capture the essence of China policy behaviors. Separating reconstructed reality from objective reality, this study captures the former by exploring pertinent indicators such as high technology trade or research indicators. Major decision makers from the cabinet to the bureaucracy hold hostile views against China, so they interpret the given information pessimistically and urge policy actions, regardless of U.S. leadership in high technology sectors. As a result, their belief system reconstructs negative rhetoric and pushes the Bush administration to counteract the national security threat raised by China. As China Rule presents a comprehensive message to China by elevating the issue to national security concerns, it introduces a crucial case to buttress recalibration of US China policy and to provide implications in US-China technology competition.
\end{abstract}

Keywords: export control policy, US foreign policy, high technology, securitization, China Rule

\footnotetext{
* Sanghyun Han (a123ll@snu.ac.kr) is an M.A. candidate at the Department of Political Science and International Relations, Seoul National University (SNU). This research was supported by College of Social Science Graduate Research Grant, SNU. The author sincerely thanks Professor Sangbae Kim, Professor Taeeun Song, Dr. Jongmin Yang, Professor Jin Mun Jeong, Dr. Joshua Eisenman, Dr. Eugene Gholz, Yubin Kim, Danbi Lee, Hyunsu Kim, Ikhyun Lee and anonymous reviewers for invaluable comments.
}

The Korean Journal of International Studies Vol.19, No.3 (December 2021), 303-338 


\section{INTRODUCTION}

As competitive circumstances have accelerated the rivalry between the United States and China, policies against-or at least regarding-China have gained attention. Technology is clearly one of the areas where both countries have struggled to maintain or achieve superiority over one another. Because current technologies can have disruptive or unforeseen characteristics, policies considering both technology and security aspects have increased. In this sense, the impact of emerging technologies (such as artificial intelligence or quantum computing) and such as semiconductor and manufacturing capacity have been thoroughly examined by scholars (Heath 2021).

Export control policy, which substitutes pillars of technology control policy, is difficult to define within a single term. However, the policy itself concerns the policy behavior that restricts exports to certain countries with a certain purpose. It includes such policies as those prohibiting the export of certain technologies to certain countries, those designating specific corporations on an entity list, those revising the definition of specific items to limit trade, and those pondering the issue of export licenses and validity of items under export licenses (Mastanduno 1992). The US export control system diverges on controlled items based on legal status, with munitions being covered by the Department of State and dual-use items being covered by the Department of Commerce (DoC).

Specifically, the dual-use characteristics of items defines recent competition of technologies. Compared to the introduction of emerging and critical technologies, it is true that the significance of dual-use technologies is neglected in academia (Aggarwal and Reddie 2021, 3-4; Kanetake 2018, 180-185). The more new and converging technologies are introduced, it is harder to estimate how those technologies yield security or economic threats to international relations. Dual-use items or technologies totalize both private and public sectors due to necessity of high fixed costs, labeled as "prestige" or "strategic" technologies (Drezner 2019, 291-293). The only difference in typology is whether the public or private sector has dominance in the market, yet more importantly both technologies are likely to enhance the capacity of both public and private sectors. Thus, noting the significance, this paper concentrates on dual-use items controlled primarily by the DoC other than munition or general purpose technologies.

Regarding dual-use items, the Trump administration is known for having utilized a control policy over relevant technologies or components against China (Haiyong 2019, 201-211; Brown 2020). In June 2020, then-President Trump revised provision 744.21 of the Export Administration Regulations (EAR), known as the China Rule. EAR 744.21 expanded its scope to "military end users" from "military 
end use" by including "military end user" in the title. According to this revision, "any person or entity whose actions or functions are intended to support military end-uses" is subject to the US export control system (Bureau of Industry and Security 2020). After this revision, the Department of Defense, for the first time since 1999, designated 20 Chinese entities as relatng to the People's Liberation Army.

Although the Trump administration carves political grounds on export control policy against China, most studies ignore the essence or origin of the policy. Thus, it is important to briefly explore the China Rule as an origin of export control policy and an outcome of political consideration. ${ }^{1}$ Although provision EAR 744.21 was expanded by the Trump administration, studies mostly neglect or unwittingly ignore the background of the very first version of the tailored-policy. It is noteworthy that the policy originated in 2007 and was the creation of the Bush administration which promulgated the final rule of "Revisions and Clarification of Export and Reexport Controls for the People's Republic of China" on the 2007 summating China Rule (Bureau of Industry and Security 2006b). Most of the export control policies toward China after the Cold War have been grounded on or influenced by this rule.

This begs the question-why did the Bush Administration implement this rule specifically in 2007? Given that policy implementation typically takes deliberate time and effort, which factor motivated the Bush Administration to draw China Rule? Compared to the recent focus on export control policy, why does the field of international relations neglect its original outcome as a crucial case? What are the academic contributions and policy implications of analyzing China Rule as a policy behavior? To examine these questions, this paper reviews the existing literature on dual-use export control policy and argues that a solid approach underscoring human decision makers is necessary. The theoretical framework that combines foreign policy analysis literature and the concept of securitization is elaborated in the following section. Then, high technology-relevant indicators are provided to construct an understanding of the objective circumstance between the US and China as so-called input in the fifth section. However, how policymakers perceive this objective and their subjective interpretation is far

\footnotetext{
${ }^{1}$ The scope of this paper focuses on China Rule during the Bush administration. Export control policy towards China during the late 1990 s is peculiar in that anti-China sentiment was triggered by propaganda or unreasoned rationale in the Cox report (Johnston, Panofsky, Capua, and Franklin 1999). Given the satellite launch failure in 1996, export control policy back then specifically aimed at the Chinese aerospace sector, not at general industries (Bureau of Industry and Security 1999). However, unlike the late 1990s, China Rule has a symbolic meaning by directly targeting China as a potential competitor. Therefore, the data and evidence during the Bush administration from the early 2000s are primarily examined in this paper, beyond the late 1990 s of Clinton administration.
} 
more crucial than any other explanation. Thus, the sixth section demonstrates the application of belief systems and the process of reconstruction. The paper concludes by suggesting that the China Rule is evidence for emphasis on national security from the mid-2000s onward, and that the policy is considered as an effective measure against China.

\section{LITERATURE REVIEW}

Given technologies converging with economic and security sectors (Blackwill and Harris 2016, 33-43; McCormick et al. 2020; Williams 2020, 77-81), the complexity of export control policy makes it almost impossible to pinpoint specific drivers on policy behavior. Since defining export control policy makes it hard to capture policy practices itself (Dobson 2002, 7), policies on dual-use items are mostly associated with legal approaches by law. Within international relations, few work has been done on export control policy in particular; yet, scholars have tried to answer the motivation behind export control policy using two broad approaches.

Various domestic factors drive the control policy. power competition between political forces (Cupitt 2000), structure of political institution (Drezner 2001), bureaucratic manners (Mastanduno 1998) or even public events such as elections (Drury 2000, 17-36) are likely to be determinants for export control policy. However, a domestic politics-based approach ignores the surrounding international environment and identifies the policy outcome as the sole result of domestic politics. In this regard, this narrow approach fails to capture the overall scope of the policy. Additionally, not every political force or its power struggle is germane to export control policy. Approaches underscoring domestic factors ignore that an administration is the bedrock of an export control policy. An administration takes the lead role in coordinating all relevant bureaus (Long 1989; Aggarwal and Reddie 2021).

On the other hand, structural factors are likely to formulate export control policy. Noting that the competitiveness of international system measured by polarity accelerates technology adoption (Milner and Solstad 2021), international structure affects export control policy especially technology sector. The most studied case is Coordinating Committee for Multilateral Export Controls (CoCom), a multilateral organization to control trade to Soviet countries, which transformative structure resulted in the elimination of the organization (Qingmin and Hyer, 2001; Clarke and Johnston 1999; Rajeswari 1998). Foreign availability or trade dependency are other structural factors to motivate export 
control policy (Mastanduno 1985; Kim 2017). Successful export control policy hinges on whether a country has an alternative partner such as an alliance in the system. Specifically, Pryor (2018) empirically tests three assumptions based on structural, perceptual, and domestic factors and concludes neither threat perception nor domestic industries are essential as trade dependency.

Both approaches overlook that the export control policy is an outcome of decision makers who have the authority to do so. As Hudson $(2005,4)$ pointed out, theories of international relations "provide much more insight into structure than agency." Recognizing policy as behavior or action led by human decision makers creates a space for human agency within foreign policy. Meanwhile, structural analysis alone cannot recapitulate the whole notion of policy behavior by overlooking the will of human agency. This is because system-level theories postulate unitary and rational actors while domestic-political theories such as foreign policy analysis concern themselves with non-unitary and unit-level attributions (Fearon 1998, 298-302). In this respect, neoclassical realism could offer guidance by mediating systemic factors and foreign policy (Rose 1998, 147-154). Nevertheless, neoclassical realism still formulates systemic elements as independent variables, perpetrating the error of omitting "human decision makers."

Above of all, some research circumvents the dilemma of choice by combining both structural and domestic politics. Meijer (2016) identifies US export control policy as a dependent variable, alongside structure of international system and competing domestic political coalitions as independent variables. Moreover, Lipson (1999) points out that no single theory can explain control policy and utilizes realism, neoliberalism and constructivism to elaborate on the dismissal of CoCom. Accordingly, export control policy is characterized by polarity, trade interdependency, and reputation to abide by international regime. Cheng and Gill (2013) discuss five relevant factors: threat perception, economic and foreign relationship, perception of policymakers, and domestic institutions.

This study establishes China Rule as policy behavior ${ }^{2}$ as dependent variable and the perceptual and cognitive aspects of decision makers in tandem with structural factors as the independent variable. Not only structural factors but also pertinent domestic factors affect policy outcomes by underscoring the perceptual side of decision making. How a country perceives other countries determines the implement of export control policy. Cheng and Gill (2013) emphasize how policy makers perceive threat and argue that a country is likely

\footnotetext{
${ }^{2}$ I use policy action and policy behavior interchangeably based on the implementation of the policy decision.
} 
to impose an export control policy if perceives the target as an adversary or potential threat (Meijer, Béraud-Sudreau, Holtom, and Uttley 2018). Whether countries perceive each other as sharing an ideological background determines control policy (Fuhrmann 2008). Regarding ideological or perceptual factors of export control policy, foreign policy analysis theories seek to explain "decisions taken by human decisionmakers," (Ripley 1993, 405-407) by linking psychological factors. This is why a novel theoretical approach is necessary.

Psychological concepts used in foreign policy analysis can determine why cognitive factors and perceptions apply when examining polices such as the China Rule. Since "external setting refers to such factors and conditions beyond the territorial boundaries of the state" (Snyder, Bruck, and Sapin 2002, 60-61), foreign policy analysis should consider the external environmental condition that is responsible for the decision makers' decisions. Still, the outcome made by the decision maker should be the priority. To establish a theoretical framework for analysis, the term 'millieu' represents a strand in the theory of foreign policy that considers both structural and domestic factors and puts particular emphasis on the human agency factor. (Sprout and Sprout 1957, 311-312). Understanding cognitive elements, or how policymakers perceive external settings, reveal why specific foreign policy actions are formulated.

Foreign policy analysis also illuminates how policymakers perceive structure. Due to scarce cognitive sources, policymakers should act upon their own judgement or perception (Snyder, Bruck, and Sapin 2002, 86-88). Given understanding of both objective material factors (such as economic or military power) and subjective assessment of them, Doshi $(2021,22)$ offers guidance on how to evaluate strategic calculation by suggesting two critical factors: the perceived relative power gap and perceived threat. His approach introduces what could be referred to as external factors and human-perceived factors. Similarly, Walt argues that "perception of intent" determines the level of threat in addition to material elements such as "aggregate power, geographic proximity, and offensive power" (Walt 1987, 22-26).

\section{THEORETICAL FRAMEWORK}

The analysis of policy behavior derives from the area of foreign policy analysis and seeks to build a robust framework for analysis. A few groundwork elements explain how a person reshapes reality or perceives circumstances (Shapiro and Bonham 1973; Hurwitz and Peffley 1987; Blum 1993). For instance, De Rivera (1968) examines how individuals reconstruct their reality via certain perceptual 
mechanisms. Jervis $(2017,3)$ provides some assumptions as to why rational decision makers misperceive. Foreign policy analysis connects psychology and foreign policy by exploring either single or multiple relevant factors through differing levels of analysis (Hudson 2014, 4-8). Holsti (1962, 245-246; 1976a, 18-54) elaborated on the relationship between belief system and decision, while focusing more on human-agency. Belief system has two separate aspects, one with images of "what has been, is, and will be" (referred to as fact) and the other with images of "what ought to be" (referred to as reconstruction). This information consequently affects the belief system, and eventually policy decisions.

Similarly, the distinction between fact and reconstruction is a necessary condition among other foreign policy theories. According to Sprout and Sprout (1957, 314), "operational environment" defines the objective reality composed of information, whereas "psychological environment" refers to how people perceive and reconstruct the operational environment. In other words, the belief system (as a subjective intermediate mechanism) mediates what information to interpret and what decision to take in each context. However, Brodin criticized that this approach leads to circular reasoning by blurring the distinction between independent and dependent variables. Thus, he proposed an alternative explanation based on Holsti's analytical framework. Brodin (1972, 104-111) specifies how a belief system is reflected and how policy action and outcome would be different, as shown in Figure 1.

Figure 1. Theoretical Framework

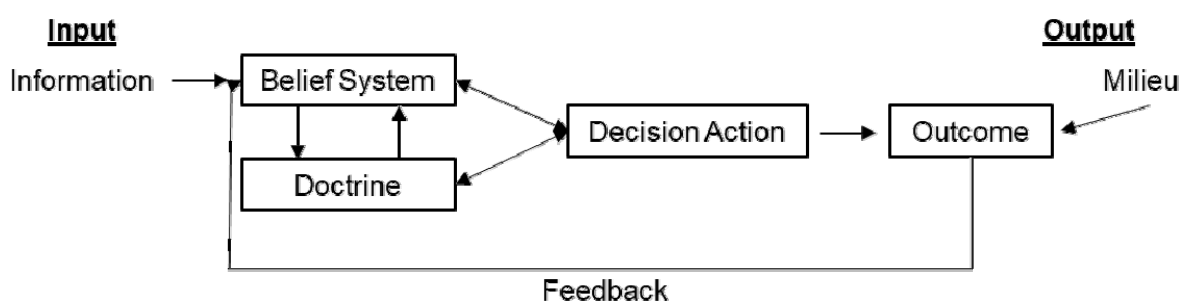

Source: Brodin 1972.

Doctrine is defined as a belief (or set of beliefs) stated and followed inclusively by those who adhere to a belief system. Thus, both beliefs and doctrines embedded within the belief system of a country may shape or restrict behavior and impact other actors' decision-making processes. Moreover, they may be subject to reciprocal effects, noting that doctrine is reliant on the belief system. 
In this sense, the interaction between belief system and doctrine represents the notion of "cognitive processes" (the fundamental process for interpreting given information) to cope with an uncertain environment and to verify circumstances (Holsti 1976b, 27). Thus, verbal behavior or texts are apposite references for capturing perceptions in cognitive processes as Doshi $(2021,17)$ suggested.

The approach taken by this paper is in line with the concept of "securitization" in two ways (Hayes 2016, 335-337). On the one hand, as argued by the Copenhagen School, what the people perceive as an existential threat is reconstructed and positioned by policymakers (or elites in their view) who urge the public to recognize the issue as one of security relevance. Borrowing from their words: "[securitization] is by labelling something a security issue that it becomes one" (Taurek 2006, 53-55). To do so, the priority should be identifying what existential threat exists. Here, use of the words "security" and "securitize" are incompatible, as more important is the "designation of an existential threat requiring emergency action" (Buzan, Wæver, and de Wilde 1988, 27). Afterwards, the threat passes through the process of "politicization" and then "securitization." If the issue eventually becomes securitized, it then becomes a national security threat (Buzan 1997, 13-14). In other words, what policymakers perceive as a threat reconstructs subjective circumstance by reframing objectivity. On the other hand, securitization relies upon "rhetorical structure" or "speech act" (Buzan 1997; Balzacq 2005, 174-176). Such verbal or oral presentation is an utterance that shapes reconstructed security (Wæver 1995, 55; Sjöstedt 2007). As verbal behavior reveals what people believe and how they perceive the "facts," the speech act reflects what actors want securitize.

Securitization is a mechanism for understanding how intersubjectively reconstructed threat plays an initial role. As a mechanism, securitization can build a bridge between belief system/doctrine and policy action. The speech act is perceived not by itself, but by contexts and conditions (Guuzzini 2011, 334-337; McDonald 2008, 570-573). When the objective circumstance-or the existential issue-turns into a security issue, actors' perceptions include how to perceive objective circumstance by operating verbal behavior. Therefore, the concept of securitization is located between the image of "what is" and the image of "ought to be." In this regard, the interaction between foreign policy analysis and securitization theory becomes a limited but intermittent theoretical framework (Sjöstedt 2017).

By using process tracing methodology, a single crucial case introduces detailed narratives and multifaceted explanations. Process tracing adopts perception as an independent variable and builds analytic links between narratives and explanations that require further resources for analysis (George 1979, 95-124; 
George and Bennett 2005, 205-232). As perception reflects foreign policy behavior, this paper in turn explores foreign policy action by examining the outcome of perceptions reflected in primary sources, such as government documents, diplomatic cables, memoirs, speeches, hearings, and media (Wylie 2004, 40). These resources help infer perception of those who receive the information by looking at their reaction (Larson 1985, 62-65).

It is noteworthy that exploring post policy action is beyond the scope of this research. The research addresses the question of how policy action goes through a cognitive process, but not whether policy action is successful. Likewise, securitization is criticized for excluding the audience inside the mechanism (Balzacq, Léonard, and Ruzicka 2016, 499-501). Whether audiences who are exposed to the securitization process need to be examined is also beyond the scope of the present research. Regardless of responses from the private sector, the China Rule was finally implemented in the United States in 2007. This paper assumes that audiences already accept an existential threat based on the implementation of policy behavior (given the role of the audience as recipients who accept and acknowledge the constructed threat), indicating that the China Rule was highly likely to be implemented, regardless of the response from the audience.

\section{WHAT IS THE CHINA RULE?}

The China Rule is composed of three elements (Fergusson 2009, 24-26). First, 20 categories were selected that directly (or are likely to) contribute to China and an approval process was furnished from the authorities. In the past, chosen products were initially banned on the grounds of terror from countries such as Cuba, Iran, North Korea, Sudan, and Syria; the policy now includes export to China by demanding a license. Additionally, particular products controlled by national security concerns presume denial of license under the rule. Second, the China Rule led to an increase in the license exemption standard of export value from 5,000 dollars to 50,000 dollars. This means those who export items exceeding 50,000 dollars in value require an End-Use Statement issued by the Chinese Ministry of Commerce. ${ }^{3}$ Lastly, if a Chinese entity satisfied specific standards listed by the DoC, export to that entity would no longer require a license for a

3 Previously above the value of 5,000 dollars, all transactions did not require an End-Use Statement (EUS) from the Chinese Commerce Department. The China Rule increased this standard to 50,000 dollars, which strengthened the exemption value of the export policy. 
certain period. Although the so-called Validated End-User (VEU) program could not apply to every item, it was beneficial for productive trade from an industrial perspective. 4

When we examine the China Rule thoroughly, it is clearly an export control policy that does not favor China, but is against it. Under Secretary for Industry and Security, David McCormick, explains that the China Rule "will achieve growth in civilian high-tech trade and enhanced security and these changes to technology export controls for China are "win-win"' (China Daily 2006b). With national security issues, the policy fortifies export control on products that significantly contributed to Chinese military end-use. In contrast, the VEU program was expected to foster civilian high-tech trade with China. However, the program drew various responses from industries about whether it can be beneficial, with a few industries strongly criticizing the China Rule (Nayan 2007, 563-565). Because it is extremely hard to get into the VEU program, the program evidently did not proceed as intended. In the case of semiconductor manufacturing equipment, only six percent takes place under the VEU program while 94 percent does so under the consistent export control policy. Additionally, Chinese authorities cooperate and approve on-site end-user verification (GAO 2008, 21-25). Therefore, the China Rule undermined US national security by disrupting civil-purpose trade (Diamond 2008, 154). Whether the negative aspects of the China Rule were intended is dubious, but it is evident that the Rule is an export "control" policy, not an export policy.

\section{INPUT: INFORMATION}

High technology becomes relevant in light of export control policy. Compared to the past when the purpose of technology was more clearly identified through either military or civilian objectives, it has become a complex issue for policymakers to distinguish its purpose today due to the advent of dual-use technology. Because it is harder to distinguish the purpose of innovation, both material impact and security dilemmas are exacerbated. For instance, additive printing, known as 3D printing technology, enables quicker and easier development of nuclear weapons by minimizing technological hurdles. The resultant nuclear arsenals facilitate security dilemmas as the technologies

\footnotetext{
${ }^{4}$ For instance, five entities (four in electronic, one in the aerial space industry) were selected for the VEU program in 2007. According to trade data, those five entities made up $18 \%$ of all licensed trade in 2006.
} 
endanger neighboring nations. This also raises the possibility of proliferation (Volpe 2019, 822-828).

Before examining how policymakers perceive information, it is crucial to examine how circumstances have been constructed through information. By exploring high-technology indicators, the given information and resulting circumstances can be reconstructed. High technology capability delimits the scope of innovation capability, defined as "the creation of new products and methods of products, constituting a source of power" (Beckley 2011, 56). As such, the means of capturing innovation capacity utilizes high technology exports, patents, and research and development (R\&D) expenditure (Gompert 2020, 122-129; Kay 2013; Beckley 2011, 63-73; Tellis et al. 2000, 65-73; Porter and Stern $2002,102-115)$. In other words, three indicators in the early 2000s will be reviewed to characterize the input stage.

First, as shown in Figure 2, the ratio of advanced technology products (ATP) being traded with China is increasing. At the same time, the United States is shown to rely upon China. Given that ATP exports to China have increased from approximately 4 percent to 7 percent, this means that China is keen to acquire US high-technology products. Chinese high technology capability is advancing, with exports surpassing the United States after 2003, as shown in Figure 3. High technology product exports (of all manufacturing exports) denote the advancement of manufacturing capability, as manufacturing is associated with producing critical technologies such as processing equipment or system management components (Tellis et al. 2000, 61-62). The US average annual growth rate from 2003 to 2008 is -1.51 percent, while Chinese growth is recorded at 5.82 percent. Likewise, as described in Figure 4, the proportion of Chinese high technology (of total manufacturing trade) has increased by 3.14 percent, while for the United States it is -1.11 percent. These indicators do not mean China has more improved capabilities or technology than the United States, but it shows that China's high technology capabilities are advancing compared to the relative decline in the United States. 
Figure 2. ATP Exports to China (percentage)

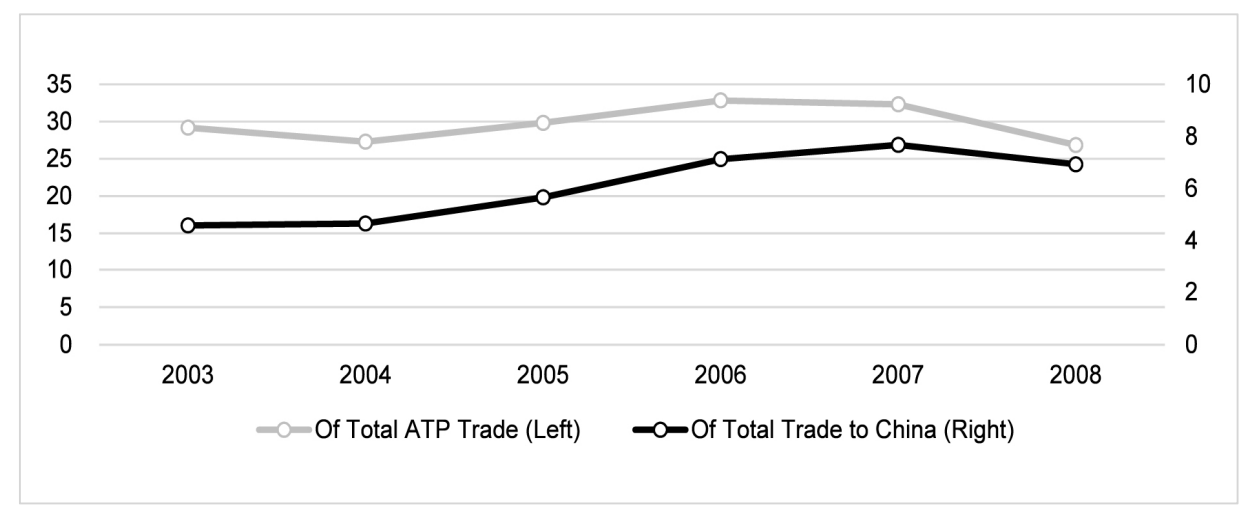

Source: United States Census Bureau. "Advanced Technology Product Data." Accessed at https://mww.census.gov /foreign-trade/statistics/product/atp/select-ctryatp.html (August 10, 2021).

Figure 3. High Technology Exports (of all manufacturing exports, percentage)

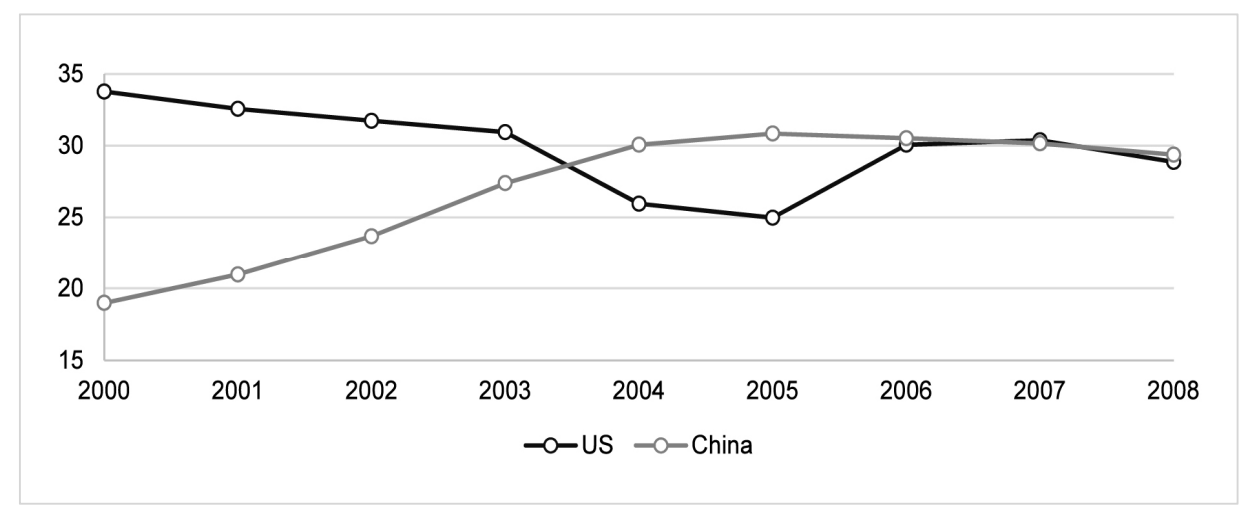

Source: World Bank. "High-Technology Export." Accessed at https://tcdata360.worldbank.org/indicators/mnfc. TX.V AL.TECH.MF.ZS?country=USA\&indicator=2010\&countries=CHN,KOR,JPN\&viz=line_chart\&years $=2000,2008$ (August 10, 2021). 
Figure 4. Medium- And High-Tech Manufactured Exports Share In Total Manufactured Exports, Value

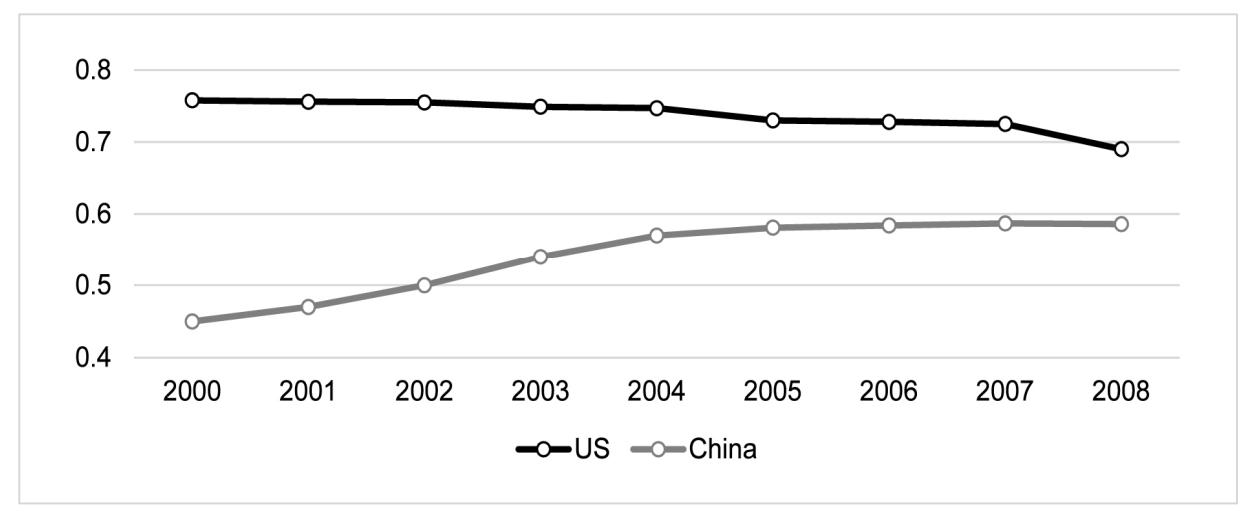

Source: World Bank. "Medium- And High-Tech Manufactured Exports Share In Total Manufactured Exports, Value." Accessed at https://tcdata360. worldbank.org/indicators/h1d4d5e37?country=USA\&indicator=3796\&countri es=CHN\&viz=line_chart\&years=2000,2008 (August 10, 2021).

Second, patents demonstrate the extent that a country can create and develop new technologies. Thus, more patents suggests a country is more likely to achieve innovation. However, the quality of patents should supplement the quantity, as patents alone do not infer innovation. In particular, patents submitted in Europe, the United States and Japan concurrently, known as a triadic patent, are a key indicator of qualified patents. Accordingly, as shown in Figure 5, the total number of triadic patents originating from the United States are decreasing whereas those from China remain consistent (approximately 15,000 per year). In addition to the number of triadic patents, the increase in submitted patents in China is remarkable. Conversely, Figure 6 combines the number of triadic patents from both countries presented as a percentage. A different trend for triadic patents appears; although the absolute number of patents is still incomparable, the trend of US decline and emerging Chinese submissions is clear. 
Figure 5. Number of Triadic and Applicated Patents

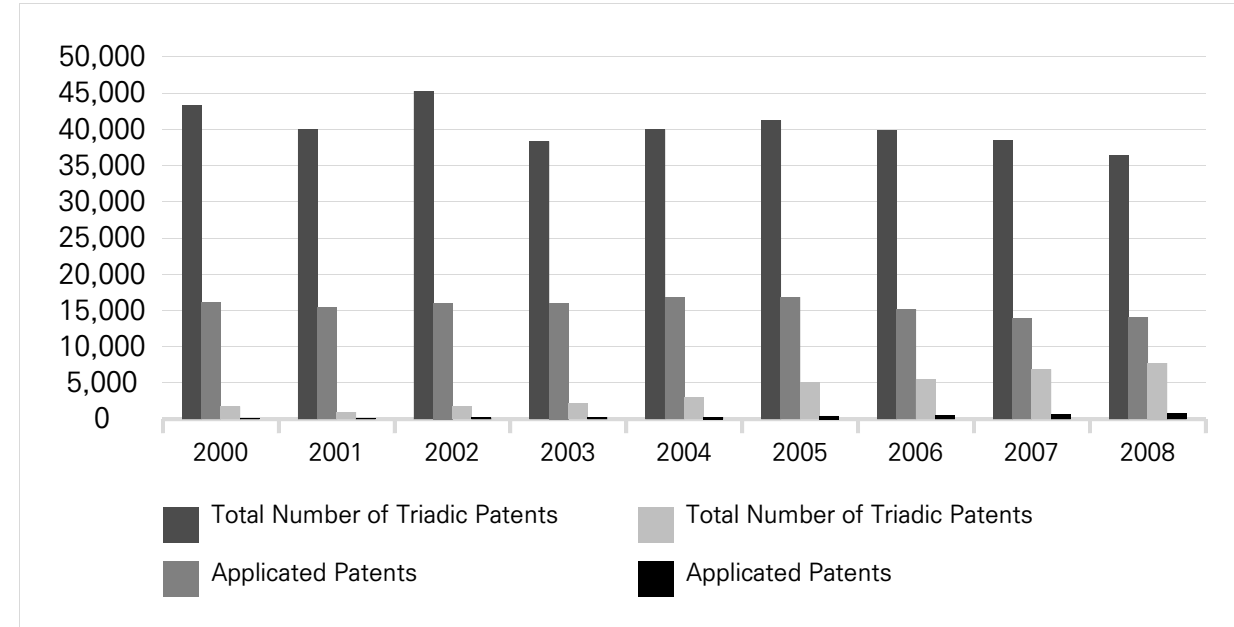

Source: China Power Team. 2016. "Are Patents Indicative of Chinese Innovation?" CS/S (February 15). Accessed at https://chinapower.csis.org/patents/ (August 10, 2021).

Figure 6. Ratios of the Number of Triadic Patents

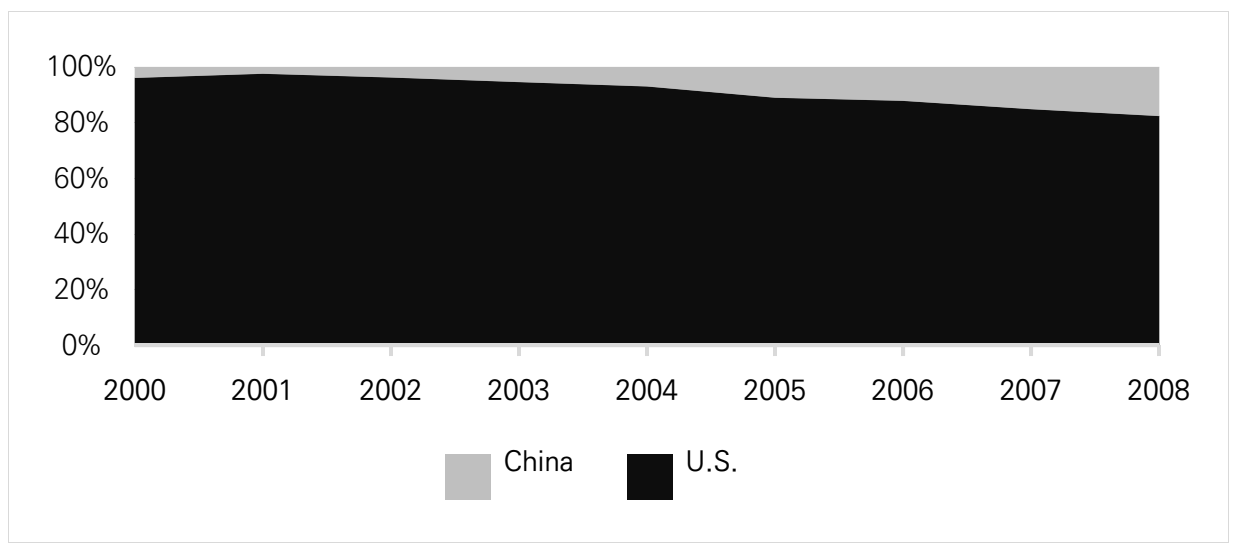

Source: China Power Team. 2016. “Are Patents Indicative of Chinese Innovation?” CSIS (February 15). Accessed at https://chinapower.csis.org/patents/ (August 10, 2021).

Lastly, Figure 7 shows sources of R\&D expenditure and the portion of gross domestic product (GDP). The line indicates the proportion of GDP that comprises $R \& D$ expenditure, while each colored square represents the total amount of expenditure. A similar trend is observed here as with patents; Chinese R\&D 
expenditure in both government and the private sector is burgeoning. In addition to innovation capability, the number of researchers could offer a plausible reason for the increase in terms of future innovation. Figure 8 shows the number of total researchers in China surpassing the United States before 2005. The number of researchers is also germane to the innovative environment and education. As a result, R\&D expenditure and the number of total researchers adumbrate how China could improve national capacity in the high technology sector and how US could maintain leadership in the science and technology sector.

Figure 7. R\&D Expenditure and Proportion

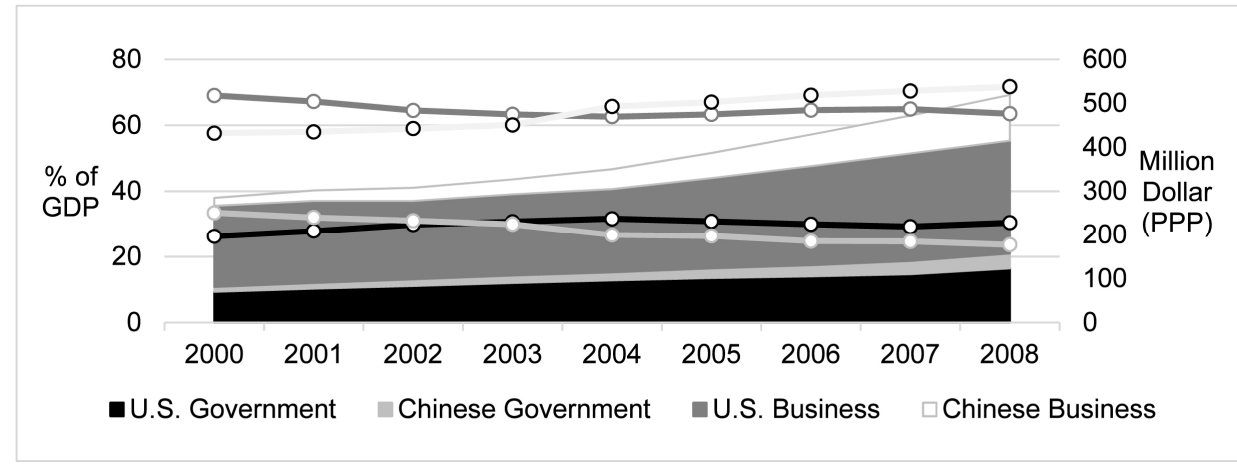

Source: OECD. "Gross domestic expenditure on R\&D by sector of performance and source of funds." Acccessed at https://stats.oecd.org/Index.aspx?DataSetCode=GERD_SOF\# (August 10, 2021).

Figure 8. Total Researchers (Full Time Equivalent)

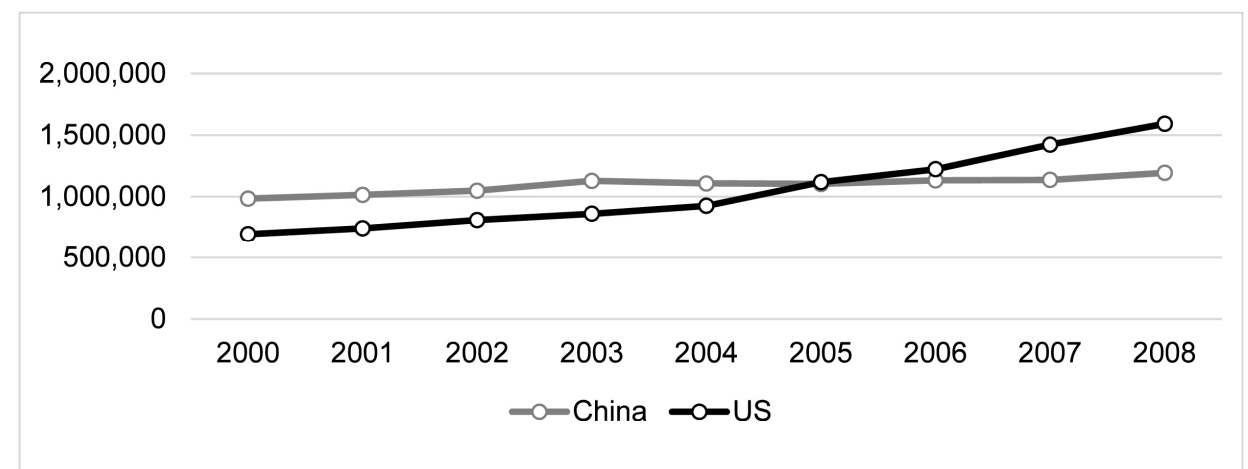

Source: "Gross domestic expenditure on R\&D by sector of performance and source of funds." Acccessed at https://stats.oecd.org/Index.aspx?DataSetCode=GERD_SOF\# (August 10, 2021). 


\section{PROCESS: BELIEF SYSTEM AND SECURITIZATION}

\section{How Washington interprets the information}

Given the information in previous sections, the view remains optimistic for the United States in terms of quantity. However, it is clear that China is closely following and even surpassing it in some respects. This situation is enough for US policymakers to reconsider the position and reevaluate policies. With respect to input information, this section examines how major policymakers such as President George W. Bush and his cabinet perceived the information and elaborated how they infuse policy action with their belief system within the securitization process.

The Bush Administration struggled in establishing a relationship with China (Garrison 2005, 165), with bifurcation as China was seen as either a cooperative partner or a competitor to be contained. This dilemma was implicitly reflected in US strategy. The US sought "a constructive relationship with China," but at the same time, Chinese pursuit of military enhancement in the region was regarded as an "outdated path" (White House 2002, 27-28). This divergence led the Bush Administration implementing various approaches based on their own assumptions (Yang 2010, 439-443). Thus it was inevitable not only to pursue a productive relationship but also to confront a competitive relationship with China (Wang 2009, 118). As a presidential candidate, George W. Bush denounced what the Clinton Administration called a strategic partnership with China, thereby pledging stricter policy action with a "clear-eyed realist" approach compared to his predecessor (Yahielski 1999). The terror attack of 9/11 shaped a space for both countries to forge. For instance, at the Asia-Pacific Economic Cooperation Summit in October 2003, President Bush stated that "[the US] seek a relationship that is candid, constructive and cooperative" with China (Dietrich $2005,213-214)$. This was an adjustment from a person who argued "tough and firm" action towards the country that is no longer a partner but a "competitor" (Yahielski 1999). There were still some disagreements on how to elaborate the "war on terror" agenda, but both countries sought to cooperate on overall terms (Zhu 2006, 114).

Within his Administration, he was not the only person with a competitive mindset against China. Most major policymakers at that point conceived China as a potential competitor. In this regard, their assigned mission was to manage China appropriately. For instance, Secretary of State Condoleezza Rice stated in her memoir that "the task of managing China's rise as economic and political power was critical" (Rice 2011, 517). Secretary of Defense Donald Rumsfeld (2011, 310) stated, "the rise of People's Republic of China and its implication for 
American strategy in Asia was perhaps an even greater and more delicate issue." In this sense, such initiatives as the Strategic Economic Dialogue or Joint Commission on Commerce and Trade were launched to handle Beijing's soaring development (Paulson 2015, 169-186). Likewise, high-level policymakers frequently expressed their concerns on Chinese advancement, especially focusing on military development. Rice said China's military buildup seemed "outsized for its regional interest," (Brinkley 2005), while Rumsfeld accused China of endangering regional security by rapidly increasing its military expenditure and by jeopardizing the value of political freedom (Blasko 2006, 263-264; Shanker 2005).

High level public officials also criticized China and urged the necessary adequate export control system to do so. They shared a similar perspective with cabinet members, but in a way that specifically targeted export control policy. Deputy Assistant Secretary of East Asia Affairs, David Sedney, explained that China (and/or Chinese entities) utilizing insufficient international treaties or regimes dealing with export control did not make enough effort on export control policy against terrorists (US-China Economic and Security Review Commission 2007, 12-13). Assistant Secretary of Defense, Peter Rodman, detected that the Chinese government had no willingness to enforce export control on weapons of mass destruction (Rodman 2006). Furthermore, Under Secretary for Arms Control and International Security, John Bolton firmly condemned Chinese behavior in not abiding by its export control policy (Bolton 2005). This series of action from policy circles vindicated a more focused and effective export control policy against China to enhance national security.

This hostile view of China also echoed in national strategies. The perspective China was reflected in National Intelligence Reports comparing similarities between United Germany in the 19th century and the rise of the United States in the 20th century and emerging powers like China or India (National Intelligence Council 2004, 9). Crucially, national security strategies published in 2006 also contended much tougher action on China: "[China] cannot stay on this peaceful path while holding on to old ways of thinking and acting" while "continuing China's military expansion in a non-transparent way" (White House 2006, 41-42). Compared with previous strategies, these particular guidelines specified a line for China not to cross. According to the Quadrennial Defense Review in 2006, China as emerging power had the potential to compete against the United States and the US should act to deter Chinese military modernization (Department of Defense 2006, 29-30).

With respect to the general view on how policymakers perceived China, the high technology sector (which closely pertains to export control policy) seemed 
to show no disparity. Noting that the United States tried to maintain its position while China was aggressively following it, it became clear that US dominance was in a peril. William Archey, President and CEO of the American Electronics Association encapsulated the challenges facing the United States: "the United States is in decline $\cdots[\mathrm{O}]$ thers are advancing quickly from behind, putting all their economic resources into moving their countries forward" (US-China Review Commission 2005, 94). Similarly, given the substantial gap between them, the United States had maintained its leadership in information and communication technologies while it acknowledged that China was closing the gap (US-China Review Commission 2004, 13-17).

China's astonishing technology development and reduced gap with the United States was of great concern. Policymakers believed that US resources were exported to China. Technology was perceived to pertain closely to Chinese military development in three ways: a) selective modernization, b) civil-military integration (or fusion), and c) acquiring advanced foreign technologies (Crane et al. 2005, 154-157). However, these are ultimately related to obtaining foreign high technologies. Chinese advancement in high technology was driven by either massive subsidies from the party or unfair trade practices (Cheng 2010, 7-9). The former implies that the Chinese government exploited the private sector to improve national capacity; the latter takes into consideration that it forces US firms in China to convey intellectual property (or obtains it illegally).

In this regard, export control policy is likely to be an effective policy action that protects intellectual property and impedes the Chinese in acquiring US high technologies (Segel 2004, 163-166). Noting that the China Rule tackles the issue with dual-use technologies, the items can be utilized for both civil and military purposes. The presumption behind this logic is that China requires and demands advanced US technologies to achieve its own military and/or economic development (Congressional-Executive Commission on China, 2003 150). After the second gulf war, China recognized the potential of applying high technologies in the military sector (Terbet and De Medeiros 2014, 308-309). Thus, China resorted to advanced technologies to nurture its military capability, even though this remains a relational power (Segal 2011, 119-122). China in turn has concentrated on modernization, focusing on whatever items exported to China can improve Chinese military capabilities.

\section{How high technology becomes a national security concern}

Unfolding the belief system and doctrines, the belief systems posited by policymakers reconstruct the given constructed reality. This belief puts pressure on the Bush Administration to resolve the threat by taking particular policy 
actions. Although the amount of Chinese R\&D expenditure was still far behind, China deployed technology as a centerpiece of national development. As the US-China Review Commission pointed out the US underestimation of Chinese development, it urged the administration to evaluate and straightforwardly assess Chinese high technology development (US-China Economic and Security Review Commission 2005b, 95-96). China even employed a "variety of methods" to achieve its national objective by utilizing technologies (Office of Science \& Technology Cooperation 2006, 42-46). Furthermore, the old approach impeded an understanding of reality. Evidence showed that Chinese high technology capacity needed to be reexamined (Pilsbury 2005, 29-38). Recalling the Sputnik moment, Pillsbury forecast that China could surpass the United States in comprehensive national power by 2020 if it maintained its science and technology improvement (Pilsbury 2005, 5-6).

US policymakers recognized what China could achieve as a threat (Intelligence Science Board 2006, 6-11). The Bush Administration acknowledged that China was increasing its position in the technology sector. While US industries no longer held competitiveness over foreign markets, US control policy tried to make a balance between strict control policy and market accessibility on China (US-China Economic and Security Review Commission 2002, 958-960). Beijing attempted to acquire US high technologies for ostensibly civilian purposes, then converting them into military purposes. One commerce official asserted that export to China should be scrutinized more than any other partner (CNN 2002). In specific cases, China initiated national-level support, such as semiconductor industries (a vital component of high technology) to accomplish military modernization. Another report on semiconductor supply stated that the United States should redesign its export control system to avoid China considering foreign availability of controlled items. The report suggested negotiating bilateral agreements and multilateral regimes to fortify export control systems (Defense Science Board 2005, 72-73). Noting that the existing export control policy showed vulnerabilities in forestalling Chinese behavior, the Bureau of Industry and Security (BIS) handled export control policy in alignment with US security and foreign policy interests (GAO 2006, 15-18). Consequently, developing pertinent export control policy to protect national security was a priority (GAO 2002, 2-17).

Policymakers concluded that the United States would confront, "real technological and manufacturing competition" (Choate and Miller 2005, 7), especially concerning circumstances facing threats from the Chinese high technology sector that translate into "an imminent threat to national security" (Lieberman 2003). Importantly, the BIS inspection concluded that "the current 
dual-use export control regulations do not prevent the Chinese military from getting US commodities.” Accordingly, revised control policy should enhance national security considerations (Office of Inspector General 2006, 17-20). The BIS was also aware of China's challenge to the United States and the subsequent national security concern. According to a BIS annual report, Chinese semiconductor capacity was expected to arise as a "security concern" as long as the United States allowed exports of relevant equipment and technologies to China (Bureau of Industry and Security 2003). Even China acknowledged that it needed more time to build an intellectual property protection system, which meant it had not prepared for apposite systems to protect US high technologies. The United States imminently required its own measures and thereby could not guarantee candid usage of US technologies ("USTR/DOC Delegation Meeting" 2006). Accordingly, the Bush Administration demanded stricter and stronger export control systems against China for advanced technologies such as semiconductor manufacturing by vesting authority to the BIS to censure trade (Defense Science Board 2005, 10-11).

The China Rule was initially proposed on July 6, 2006 to safeguard US high technologies from China. Commerce Secretary Carlos Gutierrez stated that "this new rule strikes the right balance in our complex relationship with China (China Daily 2006a)." After all, the policy aimed at "not permitting exports that would make a material contribution to the PRC's military capability (Bureau of Industry and Security 2006a, 38313)." Even before the China Rule was implemented, Under Secretary David McCormick visited China. While delivering his speech to Huawei employees, he only emphasized two points: intellectual property protection and the risk of dual-use technology diverting to the Chinese military. Although some US firms located in China complained about the potential outcome of export control policy during his trip, there was no recorded answer from him ("USDOC BIS Under Secretary" 2006). Eventually, the China Rule was finalized in 2007, a year after its proposal.

Securitization of the high technology sector and its outcome indicate how Washington robustly set the ground of security concerns against China. The number of controlled items reduced to 31 in 20 individual categories from an initial 47 in 27 categories. This curtailment was yielded by the balance between cynical responses from industries and national security interests. At the same time, it is true that if the United States can control an item that China acquired from other countries, this could abrade US industrial competitiveness. In this sense, the China Rule might have hampered economic interest (Diamond 2008, 173-182). Nevertheless, items that no longer possess monopolistic properties were removed (Palmer 2007), in that already-securitized policy action called for 
stringent export control on China. Bi Jingquan, Vice Chairman at the National Development and Reform Commission in China, argued that "modernization of China's military is an inevitable trend" and "its military modernization is not in collision with US interests" (“U.S. Export Controls" 2006). Even the overall export control system was evaluated as vulnerable (GAO 2007). This kind of rhetoric accelerated the Bush Administration's urges for stricter control policies against China taking Chinese military concerns into account (White House 2008).

The apparent purpose of the China Rule was to promote civilian high technologies while protecting national security (China Daily 2006a; Blair and Hills 2007, 70-72). Nevertheless, the latter was predominant, as seen through the securitization process. Assistant Secretary for Export Administration, Christopher A. Padilla, stated how challenging it was to create a relationship with countries as neither adversary nor ally, like China. Establishing a suitable export control policy towards them should therefore be dealt with cautiously (Committee on Foreign Affairs 2007, 19). The briefing on the China Rule presided over by the DoC and the Chinese National Development and Reform Commission vindicated the motivation of the China Rule directly: the United States was wary of China's recent military modernization, which was "the basis for the US decision not to export technologies" ("US Export Controls" 2006). During the dialogue between McCormick and Bi, McCormick highlighted that Chinese military modernization was one of the US concerns that led to the decision not to export high technologies.

In addition to military modernization, China initiated national projects to develop asymmetric weapons in the Arctic and the cyber and space arenas (Pollpeter 2015, 44-47). For example, China completed an anti-satellite weapon test in January 2007. This was just before the China Rule was enacted and the third time after the United States and Soviet Union had conducted anti-satellite weapons tests. It was necessary for the United States to counter these asymmetric capabilities as with the control of high technology. The counteraction began from the 2000s, when China made an enormous effort with asymmetric capacities. Accordingly, one of the US actions was to use export control to restrict fundamental materials exports to China. Specifically, aircraft-related products, such as gas turbine engines and knowledge of how to produce it, and relevant software were chosen for this reason.

In this context, both the United States and China cope with the China Rule in respective ways. China expresses rage by arguing that the Rule would hamper bilateral trade relationships and US firms' competitiveness ("MOFCOM Delivers Letter" 2006). It reiterates the same criticism at the US-China High Technology and Strategic Trade Working Group (HTWG), established in 2006 to foster high technology trade in both countries. In this regard, "[China] was eager to modify 
or postpone" China Rule to get access in US high technologies such as aviation, electronics, and software (Paulson 2015, 200). However, the United States also recapitulates legitimacy of the restriction as long as high technology trade with China is connected to military development ("US-China High Technology" 2007). Furthermore, Padilla visited like-minded countries (such as France, Sweden and Germany) to explain the motivation of the China Rule and urge them to comply the US export control policy on high technologies that could support Chinese military development ("Export Control Bilats" 2006; "Export Control Bilats" 2007a; "Export Control Bilats" 2007b). This action indicated that the United States was highly motivated to deter Chinese military development by using export control policy to remove foreign availability and to manage high technology exports to China (Wassenaar Arrangement Secretariat 2003). 5

Hence, the China Rule presented a well-grounded message to China by cultivating the issue of security. How to react to Chinese behavior has never been a salient issue, whereas there was also no firm action against China due to bifurcated voices in the Bush Administration (Qingguo 2006, 24-30). On the contrary, the China Rule was the outcome of Washington's perception towards China and securitization process. From 2002, policymakers recognized Chinese development and its high technology acquisitions from the United States. The issue was continuously evoked as a matter of national security requiring policy behavior to counteract. As mentioned, this became an imminent threat and national security concern. High technology trade with China underwent the securitization process regardless of whether Chinese advancement in high technology was driven by massive subsidies from the party or unfair trade practices (Menaldo and Wittstock 2021, 10-12). After all, it seemed urgent that the increasing Chinese national capabilities would jeopardize US dominance. Washington perceived China as a potential threat and chose to uphold securitization of high technology trade, and thereby the China Rule can be understood to be a policy behavior.

\footnotetext{
${ }^{5}$ Padilla mentioned the consensus from the Wassenaar Arrangement reached in 2003: if the product was suspected as military end-use, the authority should enact appropriate policy not to export. This statement showed that the U.S. had tried to constrain Chinese with both unilateral policy and multilateral actions.
} 


\section{CONCLUSION}

Even though the analysis of China Rule as a countermeasure seems obvious, this paper is novel in a way that connects structural factors and perception of them by underscoring policymakers. The rationale behind China Rule should take securitization of high technology sector into consideration. Regardless of the fact that US was still a forerunner compared with China, policy makers conceive US as vulnerable and perilous. Their belief system reconstructs the environment and considers Chinese outstanding technology development as a national-level threat beyond economic or trade issues. At the same time, Chinese behavior to develop asymmetric or unconventional arsenals triggers countermeasures from Washington. Especially for the high technology sector where decision makers recognized US dominance over China, policy behavior is necessary and should be adopted in a timely manner. The China Rule is the eventual outcome of perception and national security policy. Even after China Rule was finalized, the voice of enhancing export control system was preserved as a result of the securitization process.

The China Rule in the Bush Administration set the foundation for recent US policy behaviors. While Thomas Christensen, Deputy Assistant Secretary of East Asian Affairs from 2006 to 2008, stated that the China Rule is "a healthy balance between economic opportunities and US national security," his evaluation of the China Rule misrepresented the prevalent security environment (Christensen 2015, 317). Essentially, the China Rule indicates that export control policy originated from the mid 2000s during the Bush Administration. In addition to hawkish rhetoric from the mid 2000s, the high technology sector ascends from a problem to a national security concern in the view of the Bush Administration. Relevant indicators gave policymakers the perception that China was soaring whereas the United States was in relative decline. Given that the gap between the United States and China was still substantial, export control policy was an effective policy behavior to forestall security-focused outcomes.

The initial position taken by President Bush tried to focus attention on domestic rather than international issues (Daalder and Lindsay 2003, 62-67), although he placed his foreign policy capacity mostly on either China or Russia. Still, his main focus was on domestic politics (Garrison 2005, 165). However, the 9/11 terror attack instigated a tremendous change in his policy direction: the war on terror and non-proliferation became the new focus. Thus, these two concerns dominate the case study of foreign policy in the Bush Administration. In retrospect, Secretary Rice writes a significant amount on the Iraq war and the Middle East region, whereas documenation on China is relatively limited (Rice 2008, 2-14). 
Consequently, analysis of foreign policy in China is neglected under studies of the war on terror (Roberts 2014, 68-69).

In contrast to the non-proliferation rhetoric, some argue that the Bush administration's foreign policy towards China should be reevaluated. China policy during the first and second terms of the Bush Administration is hard to define, but his policy is mostly to engage with China (Johnston 2019, 107-109). Engagement implies that China would contribute more to multilateralism and pursue common interests on the right path (Christensen 2009, 90-93). Thus, foreign policy regarding China became a priority. For China, this support could have been seen as an opportunity to foster cooperation with China; the Chinese supportive attitude was even shocking for anti-China forces at that time (Yang 2010, 442). The logic behind engagement was the belief that China could be a liberalized and democratized nation by adopting a market economy (Rice 2011). However, the evaluation of China policy in the Bush Administration is controversial. Despite divergence on conflicting areas, both countries still share common ground on economic issues (Paulson 2008, 59-77). On the one hand, his policy failed to truly engage with China and paved the way for China to solidify its status (Blustein 2019). On the other hand, the engagement policy could be labeled as "successful" in terms of postulated US policy objectives, even though China has not revised its political system as the administration foresaw (Pethokoukis 2019, 71-80; Roberts 2014, 71-80).

The engagement rhetorics makes China Rule an obscure and a trivial case and veils the essence of US policy behaviors against China. On the contrary, the China Rule purports that the Bush Administration regarded China as not only a target to engage, but also a target to restrain. The Bush Administration contained elements of engagement, but balancing elements against China were also implemented (Zhao 2012, 386-389). China Rule policy behavior as the outcome of securitization indicates that the Bush Administration sought to prevent security concerns evoked by China. The voice of the China Rule is unblemished in that national interests in both countries were incompatible unlike what Lindsay $(2011,766-777)$ argued. In this sense, there was a proportion of security in the relationship with China and a competitive environment predominating in the high technology sector. Given that in 2011 the Obama Administration was known for its "reorientation towards Asia" or "pivot to Asia," this argument needs to be recalibrated that reorientation began in the mid 2000s (Silove 2016, 61-67). Similarly, noting the characteristics of Bush's cabinet, China is located somewhere between "congagement" and "containment" (Baum 2001, 200-203).

To gain leadership in the recent US-China competition, Trump and Biden administrations operated the China Rule in a different way. The Trump 
administration had sought unilateral export control policy by expanding the jurisdiction of China Rule. It established the Military End-User list to implement an enlarged China Rule, designating 57 Chinese entities in the list. On the other hand, Biden administration has pursued a multilateral export control policy by engaging international regimes or launching initiatives with like-minded countries. At the inaugural meeting of the US-EU Trade and Technology Council, US Trade Representative Tai said, "We affirm that a multilateral approach to export controls is most effective (US Trade Representative 2021)." To this end, the Biden administration is likely to reflect consultations and agreements into the China Rule although little substantial action has been taken so far. While export control policy is an area where both share consensus on the effective means to control high technologies, the way to approach China Rule likewise shows disparity. Therefore, application of the China Rule is in alignment with US strategy to utilize high technologies as statecraft, which reproduces structural reality and is decided by decision makers. 


\section{REFERENCES}

Aggarwal, Vinod K and Andrew W. Reddie. 2020. "New Economic Statecraft: Industrial Policy in an Era of Strategic Competition.” Issues and Studies 56(2), 1-29.

Balzacq, Thierry. 2005. "The Three Faces of Securitization: Political Agency, Audience and Context." European Journal of International Relations 11(2), 171-201.

Balzacq, Thierry, Sarah Léonard, and Jan Ruzicka. 2016. "Securitization' revisited: theory and cases.” International Relations 30(4), 494-531.

Baum, Richard. 2001. "From "Strategic Partners" to "Strategic Competitors": George W. Bush and the Politics of U.S. China Policy." Journal of East Asian Studies 1(2), 191-220.

Beckley, Michael. 2011/12. "China's Century? Why America's Edge Will Endure," International Security 36(3), 41-78.

Blair, Dennis C. and Carla A. Hills. 2007. U.S.-China Relations: An Affirmative Agenda, A Responsible Course. New York, NY: Council on Foreign Relations.

Blasko, Dennis J. 2006. "Rumsfeld's Take on the Chinese Military: A Dissenting View." Current History 105(692), 263-269.

Blum, Douglas W. 1993. "The Soviet Foreign Policy Belief System: Beliefs, Politics, and Foreign Policy Outcomes." International Studies Quarterly 37(4), 373-394.

Blustein, Paul. 2019. "The Untold Story of How George W. Bush Lost China," Foreign Policy (October 2). Accessed at https://foreignpolicy.com/2019/ 10/04/the-untold-story-of-how-george-w-bush-lost-china/ (August 19, 2021).

Bolton, John R. 2005. "Coordinating Allied Approaches to China." Remarked Co-Sponsored by the Tokyo American Center and Japan Institute for International Affairs (February 7). Accessed at https://2001-2009.state. gov/t/us/rm/41938.htm (July 20, 2021).

Brinkley, Joel 2005. “Rice Warns China to Make Major Economic Changes.” NeW York Times (August 19). Accessed at https://www.nytimes.com/2005/08/ 19/politics/rice-warns-china-to-make-major-economic-changes.html (August 13, 2021).

Brodin, Katarina. 1972. "Belief Systems, Doctrines, and Foreign Policy." Cooperation and Conflict 7(2), 97-112.

Brown, Chad P. 2020. "How Trump's export curbs on semiconductors and equipment hurt the US technology sector.” Trade and Investment Policy 
Watch (September 28). Accessed at https://www.piie.com/blogs/trade-and -investment-policy-watch/how-trumps-export-curbs-semiconductors-a nd-equipment-hurt-us (August 8, 2021).

Bureau of Industry and Security. 1999. "Entity List: Addition of Entities located in the People's Republic of China; and Correction to Spelling of One Indian Entity Name." Federal Register 64(103), 28909-28910. . 2003. "Annual Report Fiscal Year 2003.” Accessed at https://www.bis.doc. gov/index.php/documents/policy-guidance/923-bis-annual-report-fy-20 03/file (August 5, 2021). . 2006a. "Revisions and Clarification of Export and Reexport Controls for the People's Republic of China (PRC); New Authorization Validated End-User." Federal Register 71(129). . 2006b. "Revisions and Clarification of Export and Reexport Controls for the People's Republic of China (PRC); New Authorization Validated End-User; Revision of Import Certificate and PRC End-User Statement Requirements." Bureau of Industry and Security June 17. Accessed at www.federalregister.gov/documents/2007/06/19/E7-11588/revisions-an d-clarification-of-export-and-reexport-controls-for-the-peoples-republi c-of-china-prc (July 7, 2021).

. 2020. "Expansion of Export, Reexport, and Transfer (in-Country) Controls for Military End Use or Military End Users in the People's Republic of China, Russia, or Venezuela." Bureau of Industry and Security April 28. Accessed at www.federalregister.gov/documents/2020/ 04/28/2020-07241/expansion-of-export-reexport-and-transfer-in-countr y-controls-for-military-end-use-or-military-end (July 7, 2021).

Bush, George W. Decision Points. New York, NY: Crown Publisher.

Buzan, Barry. 1997. "Rethinking Security after the Cold War." Conflict and Cooperation 32(1), 5-28.

Buzan, Barry, Ole Wæver, and Jaap de Wilde. 1988. Security: A New Framework for Analysis. Boulder, CO: Lynne Reiner.

Cheng, Dean. 2010. "Export Controls and the Hard Case for China." Backgrounder (2501).

Cheung, Tai Ming and Bates Gill. 2013. "Trade versus security: How countries balance technology transfers with China." Journal of East Asian Studies 13(3), 443-456.

China Daily. 2006a. "US to boost high-tech trade with China." China Daily (June 10). https://www.chinadaily.com.cn/china/2006-06/10/content_613560.htm (August 10, 2021). . 2006b. "US Curbs Hurt Bilateral Trade." China Daily(June 20). Accessed 
at http://www.china.org.cn/english/BAT/214430.htm (August 6, 2021)

China Power Team. 2016. "Are Patents Indicative of Chinese Innovation?" CSIS (February 15). Accessed at https://chinapower.csis.org/patents/ (August 10, 2021).

Choate, Pat and Edward A. Miller. 2005. "U.S.-China Advanced Technology Trade." An Analysis for U.S.-China Economic and Security Review Commission (April).

Christensen, Thomas J. 2009. "Shaping the Choices of a Rising China: Recent Lessons for the Obama Administration." Washington Quarterly 32(3), $89-104$.

. 2015. The China challenge: shaping the choice of a rising power. New York, NY: W. W. Norton \& Company.

Clarke, Duncan L. and Robert J. Johnston. 1999. "U.S. Dual-Use Exports to China, Chinese Behavior, and the Israel Factor: Effective Controls?." Asian Survey 39(2), 193-213.

CNN. 2002. "U.S. tech exports eye 'China military threat'." CNN (January 17). Accessed at http://www.cnn.com/2002/US/01/17/china.tech/index.html (August 14, 2021).

Committee on Foreign Affairs. 2007. "Export Controls: Are We Protecting Security and Facilitating Exports?." Hearing Before the House Subcommittee on Terrorism, Nonproliferation, and Trade, 110th Congress 1st Session (July).

Congressional-Executive Commission on China. 2003. "Is China Playing by the Rules? Free trade, Fair Trade, and WTO Compliance.” Hearing Before Congressional-Executive Commission on China, 108th Congress, 1st Session (September).

Crane, Keith, Roger Cliff, Evan Medeiros, James Mulvenon, and William Overholt. 2005. Modernizing Chinese Military: Challenges and Constraints. Santa Monica, CA: Rand Corporation.

Cupitt, Richard T. 2000. Reluctant Champions: U.S. Presidential Policy and Strategic Export Controls. New York, NY: Routledge.

Daalder, Ivo H. and James M. Lindsay. 2003. America Unbounded: The Bush Revolution in Foreign Policy. Washington, DC: Brookings Institution Press.

Defense Science Board. 2005. High Performance Microchip Supply. Washington, DC: Office of the Under Secretary of Defense For Acquisition, Technology, and Logistics.

Department of Defense. 2006. Quadrennial Defense Review Report. Washington, DC: Department of Defense. 
De Rivera, Joseph. 1968. The Psychological Dimension of Foreign Policy. Columbus, OH: C. E. Merrill.

Diamond, Andrew F. 2008. "Dueling Over Dual-Use Goods: The U.S. Department of Commerce's Misguided Attempt to Promote U.S. Security and Trade with China through Restrictive Export Controls." Brooklyn Journal of Corporate, Financial \& Commercial Law3(2), 153-184.

Dietrich, John W. 2005. George W. Bush Foreign Policy Reader: Presidential Speeches and Commentary. New York, NY: M. E. Sharpe.

Dobson, Alan P. 2002. US Economic Statecraft for Survival 1933-1991: Of sanctions, embargoes and economic warfare. London: Routledge.

Doshi, Rush. 2021. The Long Game: China's Grand Strategy to Displace American Order. New York, NY: Oxford University Press.

Drezner, Daniel W. 2001. "State Structure, Technological Leadership and the Maintenance of Hegemon." Review of International Studies 27(1), 3-25. . 2019. "Technological Change and international relations." International Relations 33(2), 286-303.

Drury, A. Cooper. 2000. "How and Whom the US President Sanctions: A Time-series Cross-section Analysis of US Sanction Decisions." In Steve Chan and A. Cooper Drury eds., Sanctions as Economic Statecraft: Theory and Practice, Hampshire: Palgrave, 17-36.

Fearon, James D. 1998. "Domestic Politics, Foreign Policy, and Theories of International Relations.” Annual Review of Political Science 1(1), 289313.

Fergusson, Ian F. 2009. "The Export Administration Act: Evolution, Provisions, and Debate." Report for Congress.

Fuhrmann, Matthew. 2008. "Exporting mass destruction? The determinants of dual-use trade." Journal of Peace Research 45(5), 633-652.

GAO. 2002. "Export Controls: Rapid Advances in China's Semiconductor Industry Underscore Need for Fundamental U.S. Policy Review." GAO-02-620.

. 2006. "Improvements to Commerce's Dual-Use System Needed to Ensure Protection of U.S. Interests in the Post-9/11 Environment." GAO-06-638. . 2007. "Vulnerabilities and Inefficiencies Undermine System's Ability to Protect U.S. Interests." GAO-07-1135T.

. "Challenges with Commerce's Validated End-User Program May Limit Its Ability to Ensure That Semiconductor Equipment Exported to China Is Used as Intended." GAO-08-1095.

Garrison, Jean A. 2005. Making China Policy: From Nixon to GW Bush. Boulder, 
CO: Lynne Rienner Publishers.

George, Alexander L. 1979. "The Causal Nexus between operational Code' Beliefs and Decision-Making Behavior: Problems of Theory and Methodology." In Lawrence Falkowski ed., Psychological Models and International Politics, Boulder, CO: Westview Press, 95-124.

George, Alexander L. and Andrew Bennett. 2005. Case Studies and Theory Development in the Social Science. Cambridge, MA: Harvard University. Gompert, David C. 2020. "Spin-on: How the US Can Meet China's Technological Change.” Survival 62(3), 115-130.

Guzzini, Stefano. 2011. "Securitization as a casual mechanism." Security Dialogue 42(4-5), 329-341.

Hayes, Jarrod. 2016. "Identity, Authority, and the British War in Iraq." Foreign Policy Analysis 12(3), 334-353.

Haiyong, Sun. 2019. "U.S.-China Tech War: Impacts and Prospect." China Quarterly of International Strategic Studies 5(2), 197-212.

Heath, Timothy R. 2021. "U.S. Strategic Competition with China: A RAND Research Primer." Perspective (June). Accessed at https://www.rand.org/ pubs/perspectives/PEA290-3.html (September 10, 2021).

Holsti, Ole R. 1962. "The Belief System and national Images: A Case Study." Journal of Conflict Resolution 6(3), 244-252.

1976a. "Foreign Policy Formation Viewed Cognitively." In Robert Axelord ed., Structure of Decision, Princeton, NJ: Princeton University Press, 18-54.

. 1976b. "Cognitive Process Approaches to Decision-Making." American Behavioral Scientist 20(1), 11-32.

Hudson, Valerie M. 2005. "Foreign Policy Analysis: Actor-Specific Theory and the Ground of International Relations." Foreign Policy Analysis 1, 1-30. . 2014. Foreign Policy Analysis: Classic and Contemporary Theory Second Edition. Lanham, MD: Rowman \& Littlefield.

Hurwitz, Jon and Mark Peffley. 1987. "How Are Foreign Policy Attitudes Structured? A Hierarchical Model." American Political Science Review 81(4), 1099-1120.

Intelligence Science Board. 2006. The Challenge of New S\&T Landscape. Washington, DC: Office of Director of National Intelligence.

Jervis, Robert. 2017. Perception and Misperception in International Politics New Edition. Princeton, NJ: Princeton University Press.

Johnston, Alastair Iain. 2019. "The Failures of the 'Failure of Engagement' with China.” Washington Quarterly 42(2), 99-114.

Johnston, Alastair Iain, W. K. H. Panofsky, Marco Di Capua, and Lewis R. 
Franklin. 1999. The Cox Committee Report: An Assessment. Stanford, CA: Center for International Security and Cooperation.

Kanetake, Machiko. 2018. "Balancing Innovation, Development, and Security: Dual-use Concepts in Export Control Laws.” In Neil Craik, Cameron S. G. Jefferies, Sara L. Seck, and Tim Stephens eds., Global Environmental Change and Innovation in International Law, Cambridge: Cambridge University Press, 180-200.

Kay, Sean. 2013. “America’s Sputnik Moments.” Survival 55(2), 123-146.

Kim, Dong Jung. 2017. "Trading with the enemy? The futility of US commercial countermeasures against the Chinese challenge." The Pacific Review 30(3), 289-308.

Larson, Deborah Welch. 1985. Origins of Containment: A Psychological Explanation. Princeton, NJ: Princeton University Press.

Lieberman, Joseph I. 2003. "White Paper: National Security Aspects of the Global Migration of the U.S. Semiconductor Industry." Accessed at http://silicontaiga.ru/article/files/1761_1.pdf (August 7, 2021).

Lindsay, James M. 2011. "George W. Bush, Barack Obama and the future of US global leadership.” International Affairs 87(4), 765-779.

Lipson, Michael. 1999. "The reincarnation of CoCom: Explaining post - cold war export controls." The Nonproliferation Review 6(2), 33-51.

Long, William J. 1989. U.S. Export Control Policy. New York, NY: Columbia University Press.

Mastanduno, Michael. 1985. "Strategies of Economic Containment: U.S. Trade Relations with the Soviet Union.” World Politics 37(4), 503-531. . 1992. Economic Containment: CoCom and the Politics of East-West Trade. Ithaca, NY: Cornell University Press.

. 1998. "Trade as Strategic Weapon: American and Alliance Export Control Policy in the Early Postwar Period.” International Organization 42(1), 121-150.

McCormick, David H., Charles E. Luftig, and James M. Cunningham. 2020. "Economic Might, National Security, and the Future of American Statecraft." The Strategist (July 9). Accessed at https://www.atlanticcoun cil.org/wp-content/uploads/2020/06/Economic-Might-National-Security -and-the-Future-of-American-Statecraft.pdf (July 10, 2021).

McDonald, Matt. 2008. "Securitization and the Construction of Security." European Journal of International Relations 14(4), 563-587.

Meijer, Hugo. 2016. Trading with the enemy: The making of US Export Control Policy toward the People's Republic of China. Oxford: Oxford University Press. 
Meijer, Hugo, Lucie Béraud-Sudreau, Paul Holtom, and Matthew Uttley. 2018. "Arming China: Major powers' arms transfers to the People's Republic of China." Journal of Strategic Studies 41(6), 850-886.

Menaldo, Victor and Nicolas Wittstock. 2021. "Does Technology Transfer from the US to China harm American firms and consumers? A historical and analytic investigation." Working Paper Series 7.

Milner, Helen V. and Sondre Ulvund Solstad. 2021. "Technological Change and the International System.” World Politics 73(3), 545-589.

National Intelligence Council. 2004. Mapping the Global Future. Pittsburgh, PA: Government Printing Office.

Nayan, Rajiv. 2007. "US Policy on Dual-Use Technology Transfers to China." Strategic Analysis 31(4), 553-581.

OECD. "Gross domestic expenditure on R\&D by sector of performance and source of funds." Accessed at https://stats.oecd.org/Index.aspx?DataSet Code=GERD_SOF (August 10, 2021).

Office of Inspector General. 2006. "U.S. Dual-Use Export Controls for China Need to Be Strengthened.” No. IPE-17500.

Office of Science \& Technology Cooperation. 2006. "United States - China Science and Technology Cooperation." Biennial Report to the U.S. China Economic \& Security Review Commission.

Palmer, Doug. 2007. "U.S. tightens controls on military-use items to China." Reuters (June 15). Accessed at https://www.reuters.com/article/us-usachina-export-controls-idUSWAT00774920070616 (August 10, 2021).

Paulson, Henry M. 2008. "A Strategic Economic Engagement - Strengthening U.S.-Chinese Ties.” Foreign Affairs 87(5), 59-77. 2015. Dealing with China: An Insider Unmasks the New Economic Superpower. New York, NY: Grand Central Publishing.

Pethokoukis, James. 2019. "George W. Bush didn't lose China," AEIdeas (October 15). Accessed at https://www.aei.org/economics/george-w-bush-didnt-lo se-china/ (August 19, 2021).

Pillsbury, Michael. 2005. "China's Progress in Technological Competitiveness: The Need for a New Assessment." A Report Prepared for the US China Economic and Security Review Commission.

Pollpeter, Kevin. 2015. "China' s Modernization Effects and Activities in Outer Space, Cyberspace, and the Arctic." In Jae Ho Chung ed., Assessing China's Power, Hampshire: Palgrave Macmillan, 113-135.

Porter, Michael and Scott Stern. 2002. The Global Competitiveness Report 20012002. New York, NY: Oxford University Press.

Pryor, Crystal D. 2018. "Beyond Economics and Security: Strategic Export 
Control Practices in Advanced Countries." Strategic Trade Review 4(6), 45-75.

Qingguo, Jia. 2006. "One administration, two voices: US China policy during Bush's first term." International Relations of the Asia-Pacific 6(1), 23-36. Qingmin, Zhang and Eric Hyer. 2001. "US 'Dual Track' Policy: Arms sales and technology transfer to China mainland and Taiwan.” Journal of Contemporary China 10(26), 89-105.

Rajeswari, P. R. 1998. "US export control policy and Wassenaar Arrangement." Strategic Analysis 22(3), 433-444.

Rice, Condoleezza. 2008. "Rethinking the National Interest: American Realism for a New World." Foreign Affairs 87(4), 2-26. . 2011. No Higher Honor. New York, NY: Broadway Paperbacks.

Ripley, Brian. 1993. "Foreign Policy, and International Relations Theory." Political Psychology 14(3), 403-416.

Roberts, Guy. 2014. "Toward A New Understanding of George W. Bush's China Engagement: Case Studies of George W. Bush's First Term China Policy." Australasian Journal of American Studies 33(2), 65-83.

Rodman, Peter W. 2006. "China's Proliferation to North Korea and Iran, Its Role in Addressing the Nuclear and Missile Situations in Both Countries." $A$ Prepared Statement Before the US-China Economic and Security Review Commission (September 14).

Rose, Giden. 1998. "Neoclassical Realism and Theories of Foreign Policy." World Politics 51(1), 144-172.

Rumsfeld, Donald. 2011. Known and Unknown. New York, NY: Sentinel.

Segal, Adam. 2004. "Practical Engagement: Drawing a Fine Line for U.S.-China Trade.” Washington Quarterly 27(3), 157-173.

. 2011. Advantage: How American Innovation Can Overcome the Asian Challenge. New York, NY: W. W. Norton \& Company.

Shanker, Thomas. 2005. "Rumsfeld Issues a Sharp Rebuke to China on Arms." New York Times (June 4). Accessed at https://www.nytimes.com/2005/ 06/04/world/asia/rumsfeld-issues-a-sharp-rebuke-to-china-on-arms.ht $\mathrm{ml}$ (August 13, 2021).

Shapiro, Michael J. and G. Matthew Bonham. 1973. "Cognitive Process and Foreign Policy Decision-Making.” International Studies Quarterly 17(2), 147-174.

Silove, Nina. 2016. "The Pivot Before the Pivot." International Security 40(4), 45-88.

Snyder, Richard C., H. W. Bruck, and Burton Sapin. 2002. Foreign Policy Decision-Making (Revisited). New York, NY: Palgrave Macmillan. 
Sprout, Harold and Margaret Sprout. 1957. "Environmental Factors in the Study of International Politics." Journal of Conflict Resolution 1(4), 309-328.

Sjöstedt, Roxanna. 2017. "Securitization Theory and Foreign Policy Analysis." Oxford Research Encyclopedia of Politics (April 26). Accessed at http://lps3.oxfordre.com.libproxy.snu.ac.kr/politics/view/10.1093/acref ore/9780190228637.001.0001/acrefore-9780190228637-e-479 (July 20, 2021).

Taureck, Rita. 2006. "Securitization theory and securitization studies." Journal of International Relations and Development 9(1), 53-61.

Tellis, Ashley J., Janice Bially, Christopher Layne, and Melissa McPherson. 2000. Measuring National Power in the Postindustrial Age. Santa Monica, CA: Rand Corporation.

Terbet, Nicholas M. and Carlos Aguiar De Medeiros. 2014. "Military Modernization in Chinese Technical Progress and Industrial Innovation." Review of Political Economy 26(2), 303-324.

U.S.-China Economic and Security Review Commission. 2002. "2002 Annual Report To Congress." Hearing Before U.S.-China Economic and Security Review Commission (January). . 2004. "China As an Emerging Regional and Technology Power: Implications for U.S. Economic and Security Interests." Hearing Before U.S.-China Economic and Security Review Commission, 108th Congress, 2nd Session (February). . 2005a. "2005 Report to Congress," Hearing Before U.S.-China Economic and Security Review Commission, 109th Congress, 1st Session (November).

. 2005b. "China's High Technology Development." Hearing Before U.S.-China Economic and Security Review Commission, 109th Congress, 1st Session (November). . 2007. "China's Proliferation and the Impact on Trade Policy on Defense Industries in the United States and China." Hearing Before U.S.-China Economic and Security Review Commission, 110th Congress 1st Session (July).

United States Census Bureau. "Advanced Technology Product Data." Accessed at https://www.census.gov/foreign-trade/statistics/product/atp/select-ctry atp.html (August 10, 2021).

US Trade Representative. "U.S.-EU Trade and Technology Council Inaugural Joint Statement.” Accessed at https://ustr.gov/about-us/policy-offices/press-of fice/press-releases/2021/september/us-eu-trade-and-technology-council -inaugural-joint-statement (November 19, 2021). 
Volpe, Tristan A. 2019. "Dual-use distinguishability: How 3D-printing shapes the security dilemma for nuclear programs.” Journal of Strategic Studies 42(6), 814-840.

Walt, Stephen M. 1987. The Origins of Alliances. Ithaca, NY: Cornell University Press.

Wang, Chi. 2009. George W. Bush and China: Policies, Problems, and Partnership. Lanham, MA: Lexington Books.

Wassenaar Arrangement Secretariat. 2003. "Statement of Understanding on Control of Non-Listed Dual-Use Items(Agreed at the 2003 Plenary)." Accessed

https://www.wassenaar.org/app/uploads/2019/consolidated/Non-listed_ Dual_Use_Items.pdf (August 17, 2021).

Wæver, Ole. 1995. "Securitization and desecuritization.” In Ronnie D. Lipschutz ed., On Security, New York, NY: Columbia University Press, 46-86.

White House. 2002. The National Security Strategy of the United States of America. Washington, DC: White House. . 2006. The National Security Strategy. Washington, DC: White House. . 2008. "National Security Presidential Directive/NSPD-55." Accessed at https://irp.fas.org/offdocs/nspd/nspd-55.pdf (August 13, 2021).

Williams, Robert D. 2020. "Crafting a multilateral technology and cybersecurity policy.” In Ryan Hass, Ryan McElveen, and Robert D. Williams eds., The Future US Policy Toward China, Washington, DC: Brookings Institution, 77-84.

World Bank. "High-Technology Export." Accessed at https://tcdata360.worldba nk.org/indicators/mnfc.TX.VAL.TECH.MF.ZS? country=USA\&indicator= $2010 \&$ countries $=$ CHN,KOR,JPN\&viz $=$ line_chart\&years $=2000,2008$ (August 10, 2021).

"Medium- And High-Tech Manufactured Exports Share In Total Manufactured Exports, Value.” Accessed at https://tcdata360.worldbank. org/indicators/h1d4d5e37? country=USA\&indicator $=3796 \&$ countries $=\mathrm{C}$ HN\&viz=line_chart\&years $=2000,2008$ (August 10, 2021).

Wylie, Lana. 2004. "Perceptions and foreign policy: A comparative study of Canadian and American policy toward Cuba." Canadian Foreign Policy Journal11(3), 39-63.

Yang, Yi Edward. 2010. "Leaders' Conceptual Complexity and Foreign Policy Change: Comparing the Bill Clinton and George W. Bush Foreign Policies toward China." Chinese Journal of International Politics 3(4), 415-446.

Yahielski, Janine. 1999. "Bush lays out foreign policy vision." CNN (November 19). Accessed at http://edition.cnn.com/ALLPOLITICS/stories/1999/11/19/ 
bush.speech/ (August 11, 2021).

Zhu, Zhiqun. 2006. US-China Relations in 21st Century. London: Routledge. Zhao, Suisheng. 2012. "Shaping the Regional Context of China's Rise: how the Obama administration brought back hedge in its engagement with China." Journal of Contemporary China 21(75), 369-389.

2005. “USTR/DOC Delegation Meeting with VFM Yang Jiechi.” Wikileaks Public Library of US Diplomacy(June 27). Accessed at https://wikileaks.org/plu sd/cables/05BEIJING10421_a.html (August 9, 2021).

2006. “USDOC BIS Under Secretary McCormick Visit To South China." Wikileaks Public Library of US Diplomacy (June 2). Accessed at https://wikileaks. org/plusd/cables/06GUANGZHOU16447_a.html (August 9, 2021).

2006. "U.S. Export Controls: U/S McCormick's Discussion with NDRC Officials, May 23, 2006." Wikileaks Public Library of US Diplomacy (June 7). Accessed at http://wikileaks.org/plusd/cables/06BEIJING11499_a.html (August 9, 2021).

2006. "MOFCOM Delivers Letter From Vice-Premier Wu Yi for Secretary Gutierrez," Wikileaks Public Library of US Diplomacy (September 4). Accessed at https://wikileaks.org/plusd/cables/06BEIJING18558_a.html (August 7, 2021).

2006. "Export Control Bilats Between France and DOC Assistant Secretary Christopher Padilla." Wikileaks Public Library of US Diplomacy (December 7). Accessed at https://search.wikileaks.org/plusd/cables/06 PARIS7705_a.html (August 10, 2021).

2007a. "Export Control Bilats Between Sweden and DOCAssistant Secretary Christopher Padilla.” Wikileaks Public Library of US Diplomacy (January 23). Accesse $\mathrm{d}$ at https://search.wikileaks.org/plusd/cables/07STOCKHOLM77_a.html (August 10, 2021).

2007b. "Export Control Bilats Between Germany and DOC Assistant Secretary Christopher Padilla." Wikileaks Public Library of US Diplomacy(Februar y 2). Accessed at https://wikileaks.org/plusd/cables/07BERLIN219_a.htm 1 (August 10, 2021).

2007. "US-China High Technology and Strategic Trade Working Group Concludes Guidelines for Developing Bilateral High-Tech Trade and Discusses the Proposed China Rule.” Wikileaks Public Library of US Diplomacy (May 14). Accessed at https://wikileaks.org/plusd/cables/07BEIJING3207_a.ht ml (August 9, 2021).

[Received Sep 29, 2021; Revised Nov 21, 2021; Accepted Nov 22, 2021] 